\title{
The Nexus between Human Capital Development and Economic Growth in Nigeria: A Var Methodology
}

\author{
Imandojemu, Kingsley ${ }^{1,3}$, Ekperiware, Clinton. Moses phd ${ }^{1,2}$, Babatunde, J. Aina ${ }^{3 *}$ \\ ${ }^{1}$ Central Bank of Nigeria, Abuja \\ ${ }^{2}$ Obafemi Awolowo University, Ile-Ife \\ ${ }^{3}$ Central Bank of Nigeria, Abuja
}

$\begin{array}{cl}\text { Article History } & \begin{array}{l}\text { Abstract: This study investigated the relationship between human capital development } \\ \text { and economic growth in Nigeria within the period 1990 to 2018. Annual time series data } \\ \text { Received: } 25.08 .2020\end{array} \\ \begin{array}{l}\text { Accepted: } 17.09 .2020 \\ \text { Published: } 23.10 .2020\end{array} & \begin{array}{l}\text { Bulletin and the National Bureau of Statistics were used. Gross domestic product (GDP) } \\ \text { was used as proxy for economic growth. The exogenous variables for human capital } \\ \text { development were Human Capital (HC), government expenditure on education (GXE), } \\ \text { government expenditure on health (GXH), life expectancy (LE), and fertility rate (FE). } \\ \text { Journal homepage: }\end{array} \\ \begin{array}{l}\text { The vector autoregressive (VAR), Augmented Dickey Fuller (ADF) and Philip Perron } \\ \text { (PP) test were employed. The results showed that FE had an inverse significant }\end{array} \\ \text { relationship with GDP while HC, GXE, GXH, LE had a direct significant relationship } \\ \text { with GDP. A long run relation was established in the study. The paper recommended that } \\ \text { the Nigerian government should evolve practicable framework for improved investment } \\ \text { in key human capital development deliverables especially education and health which } \\ \text { remains germane to labour productivity and economic development. } \\ \text { Keywords: Human Capital Development, Poverty, Economic Growth, Inequality and } \\ \text { VAR. }\end{array}$

Copyright (C) 2020 The Author(s): This is an open-access article distributed under the terms of the Creative Commons Attribution 4.0 International License (CC BY-NC 4.0) which permits unrestricted use, distribution, and reproduction in any medium for non-commercial use provided the original author and source are credited.

\section{INTRODUCTION}

"Like slavery and apartheid, poverty is not natural. It is man-made, and it can be overcome and eradicated by the actions of human beings..." - Nelson Mandela.

\section{BACKGROUND TO THE STUDY}

The age long narrative which narrowed the bipolar pursuit of human capital development and economic growth as a problematique of developing countries battling to solve noxious bequeathed economic trajectory, as well as the repercussion of a randomly enshrined dependence on raw natural resources as a precursor to sustainable development is becoming stale. This reality that stems from the resurgence of the renewed emphasis on human capital development and economic development, in some cases exacerbated by extreme poverty which is becoming a challenge for the growing cosmopolitanism of developed countries, are increasingly universal. According to UN data, over 700 million people live in extreme poverty today without access to water, sanitation, health services, or education. More than two thirds of the extremely poor people worldwide live on a daily budget of less than USD 1.90 - the challenge, however, is by far not limited to the developing world.
In fact, 30 million indigent children grow up in the world's richest countries [1]. The current development permeates the ideology of a common humanity premised on the nonexistence of a cocoon in relation to developmental challenges. An effective response to this growing challenge requires new and innovative approaches, including institutional changes at the international level and top prioritization of the agenda in the national level. In a rather sincere approach international commitment in form of the Sustainable Development Goals articulated by the United Nations (UN) in September 2015 strives to eradicate poverty "in all its forms everywhere by 2030" with focal emphasis on the human dimension of economic development. Human capital development was identified as the prime frontier of addressing developmental challenges. Expectedly, the pursuance of human capital development became a shared goal the world over. The Federal Government of Nigeria cascaded and incorporated human capital development into the Economic Recovery and Growth plan (ERGP), a medium term plan for 2017-2020. The Economic Recovery and Growth plan was developed for the purpose of restoring economic growth while leveraging the ingenuity and resilience of the Nigerian people - the nation's most priceless assets [2]. This is understandable given that Nigeria is among the 
speediest developing nations on the globe having a human population increase rate of $3.25 \%$ as of 2016 in line with the Central Bank of Nigeria statistical bulletin [3]. It is regarded as the most populated nation in the African continent gifted with a broad variety of natural resources and makes up about one in five of Sub-Sahara Africa's people [4]. Nigeria's human population following the Central Bank of Nigeria estimation as of 2016 was 193.4 million [3]. Given Nigeria's high human population which is not the characteristics of Nigeria alone but an important characteristic of a developing country, Nigeria's population is forecasted to increase even more in the nearest future. This is expected to have either a positive or negative implication for Nigeria's economic growth as it would impact on the socio-economic variables [4]. The core of this negative impact is traceable to the seeming imbalance between population growth and diminishing resources. Firstly, the potential population would have tremendous repercussion on the countries physical resources such as land, mines, gold and mineral resources. Additionally, the socio-economic condition would be characterised by a degradation of essential social services: Education, health, housing, nutrition, and water which constitute the fulcrum of human welfare. Despite well-nigh commitment by the Federal government of Nigeria under the aegis of the ERGP to take advantage of the countries human resources, Nigeria's performance continues to trend downward. The United Nations Development Programmes (UNDP) in its 2018 report placed Nigeria in the $157^{\text {th }}$ positions in the low, Human Development category (UNDP report, 2018). By the UNDP ranking, Nigeria lagged behind Ghana, Kenya, Cabo Verde, Namibia and Congo among others which featured in the medium Human Development category. The picture that emerges from the analysis of the perspective of the country, under the historical trend scenario, is almost a nightmare. The most grievous aspect of this tableau is the steady deterioration in the quality and quantity of the countries pool of trained human resources. In many respects, Nigeria seems to be losing the battle against, illiteracy. Since 1980, there has been a sharp decline in primary school enrolment exceeding 10 percent. The retrogression and waste of children's potential are reflected in the fact that 40 percent of children of school aged 6-11 did not attend primary school, $30 \%$ of pupils drop out of primary school and only $54 \%$ transit to secondary schools [5]. According to World Bank [6] a large percentage of Nigeria's population estimated to 182.2 million remains at rather low levels of literacy and often with insufficient access to education and health care. Adenikinju [7], reported that the quality of human capital in Nigeria has deteriorated over the years. It has been weakened by low public expenditure on education and health sectors [7, 8]. It was recommended by the United Nations that developing countries should invest a minimum of $26 \%$ on education and the World Health Organisation specified at least $15 \%$ budgetary allocation on health [5]. Nigeria has not been able to meet this minimum threshold. For instance, budgetary allocation to the educational sector is relatively trivial as Nigeria spent only $3 \%$, in recent time in comparison with other developing nations like Ghana who spend $20 \%$ of its expenditure on education, Bostwana who spent a historical average of $21 \%$, Kenya who spent $20 \%$ and Uganda who spent $15 \%$ [9]. Sustainable economic development will remain illusionary in Nigeria insofar as investment in human development is still treated with levity rather than a top priority of development policy agenda. To this end, effective investment in human capital through the provision of quality education and health is a key component of economic growth and improved productivity in developing countries like Nigeria.

Surprisingly, despite the importance of human capital development indicators in adjudging the developmental strides of the country very little has been done to evaluate the nexus between human capital development and economic growth in Nigeria. Previous attempts in this area have focused on linking the relationship between education as a component of human capital development to economic growth. Adamu [10], Adelakun O. J [11], Fuente [12], Ibok and Ibanga [13] have all focused on studies that link education to economic growth, while studies on the relationship between the broad components of human capital development and economic growth were rarely conducted. As such, the investigation on the nexus between human capital development and economic growth is not only well timed but also fundamentally critical. The strong connection between human capital development, economic growth and human welfare has provoked inquiry into the aforementioned area of study. After all, central to the entire process today is the development by, of and for people irrespective of the prevailing political economic milieu.

\section{CONCEPTUAL REVIEW}

Human capital is considered as the most valuable asset and needs to be mobilized [14]. This enables people to realize their full potential, and is the primary factor driving nations' economic growth. Romele [15] defined Human capital as the totality of knowledge and skills which have been accumulated during life, through education, training, and work experience and which influence labour productivity. Frank \& Bemanke [16] as cited in OECD 2009 conceptualizes that human capital is 'an amalgam of factors such as education, experience, training, intelligence, energy, work habits, trustworthiness, and initiative that affect the value of a worker's marginal product'.

In that sense a broader perspective of human capital encompasses the entire spectrum of expenditure on health, education and social services. World Bank [17] aptly posited that human capital can be defined as the sum of a population's health, skills, knowledge, 
experience, and habits, and forms the basis for individual and societal well-being. Human capital as an economic term encompasses health, education and other human capacities that can raise productivity [18]. Health and education are two closely related human (resource) capital components that work together to make the individual more productive. One component cannot be considered important than the other [19]. Health is central to well-being and education is essential for a satisfying and rewarding life: both are fundamental to the broader notion of expanding human capability and that it has the heart of the meaning of development [20]. According to the World health Organization (WHO), health is a state of complete physical, mental and social wellbeing and not merely the absence of disease or infirmity. Adequate investment in health triggers development as only healthy people can contribute to the efficient production of output in an economy [21]. Having navigated thus far it is clear that there is a link between human capital development and economic growth even in developed economies. Developed countries need human capital to staff new and expanding government services to introduce new systems of land use and new methods of agriculture, to develop new means of communication to carry forward industrialization and to build the economic system [22]. Edame and Eturoma [23] opined that government expenditures on education raise the productivity of labour and determine productivity. Imoughe and Isamaila [24] noted that education, health care, training and investment in social services enhance and improve the human capacity which has a spillover effect on economic growth.

\section{THEORETICAL ISSUES}

In the traditional neo-classical growth model developed by Robert Solow and Trevor Swan in the 1950 s, the output of an economy grows in response to larger inputs of capital and labor (all physical inputs). To the neo-classical growth models, non-economic variables, such as human health, skills, knowledge, among others, have no function in the growth process of an economy. This line of thought was described as the Exogenous growth theory and it does not explain why countries with little capital and labor grow more than countries with abundance of these resources [25]. This study is anchored on the endogenous growth theory considering the shortcomings in the classical growth model which resulted in the endogenous growth model where the assumption of exogenous of population and technical progress was relaxed. Endogenous growth theory emerged in the 1980 s, particularly due to the works of Paul Romer and his associates in response to the postulations of the exogenous theorists. They argued that economic growth and development in most fastdeveloping economies, particularly, those of the East Asian developing countries, where the economies have continued to grow for well over three decades, demonstrated quite the contrary. The argument is that, it is not only technology, which is the main driving force accountable for maintaining such high growth performance in the economies, but that there were other factors which are outside the realm of the neoclassical growth model [25].

Romer [26] in his work titled "Increasing Returns and Long Run Growth" broadened the concept of capital to include human capital. He argues that the law of diminishing returns to scale phenomenon may not be true as is the case for the East Asian economies. The theory holds that if a firm or an economy which invests in capital (physical) also employs educated and skilled workers who are also healthy, then not only will the labor be productive, but it will also be able to use capital and technology more effectively. This will lead to a "neutral' shift in the production function and, therefore, there can be increasing rather than decreasing returns to investments. This means that technology and human capital are both endogenous to the system [25]. In line with the endogenous growth model, population and technical progress are dependent on economic conditions and can be determined by choice made by the agent of the economy [26]. A significant benefit of the endogenous growth model is its decomposition of capital into human and physical capital. Such dichotomy enables direct incorporation of population growth as a determinant of human capital and hence an endogenous variable in the growth process [27].

Other scholars of this school of thought are Lucas [28], Aharonovitz [29], Marchand, Michel, Paddison, and Pestieau [30]. The basic assumption of the endogenous growth theory is that policy measures can have an impact on the long-run growth rate of an economy. It argues that investment (subsides) on education or research and development increase the growth rate by increasing the incentive to innovate. For instance, Lucas [28] identified two sources of economic growth to include human capital accumulation due to education investments and technological progress due to learning-by-doing externalities [25]. In other words, education and learning-by-doing improve the knowledge and skills of labor in the production sector.

The endogenous theorists also assume that research and development (R\&D) is the key to the growth and development of an economy or a firm. Research and development generate new ideas or new technologies that are not common in the society. Whenever there is technological change in a given productive process, those with education or greater skills are faster in adopting the new technology [31]. In addition, the theorists assert that training of the human resources of the society is central to growth and development.

Aharonovitz [29] noted that as managers (or employees) are trained, they will become heads of production units and train more managers who will, in turn, head other production units or set up new firms 
and further train more managers. This process will be a continuous one that will lead to growth and development. This will produce development in the long run because as new firms spring up, they create employment, which will reduce poverty and improve income per capita or standard of living in the society. In the context of the study, Nigeria government policies on human capital development will affect economic growth.

\section{EMPIRICAL REVIEW}

Several studies have been carried out to examine human capital development and economic growth.

Kairo, Mang, Okeke and Aondo [32] studied the relationship between human capital development and government expenditure. Data were collected over the period 1990-2014. Augmented Regressive Distributed Lag (ARDL) and impulse response function were adopted for the estimation. The results demonstrated that both in the long and short run, government spending has remained positive but to a very large extent insignificant to human capital development in Nigeria. They noted that this perhaps account for the reason Nigeria's per capita income has remained low for a long time in the world ranking.

Obialor [33] examined the effect of government human capital investment on the economic growth of three Sub-Sahara African (SSA) countries of Nigeria, South Africa and Ghana from 1980 to 2013. The objective of the study was to analyze the growth effect of three government human capital investment variables of health, education and literacy rate on the economies of these countries; Secondary data are sourced from World Development Indicators (WDI) online database and analyzed using Co-integration techniques and Vector Error Correction mechanism (VECM) at 1 per cent and 5 per cent significance levels. The results indicated that two out of the three human capital proxy variables: Health $(\mathrm{GIH})$ and Education (GIE) showed significant positive effect on growth only in Nigeria, while literacy ratio (LR) is insignificantly positive in all countries. This study concluded that in spite of the above result, the SSA countries' economies still exhibit the potentials for enhanced economic growth in the long run judging from the VECM test results.

Adeyemi and Ogunsola [34] examined the impact of human capital development on economic growth in Nigeria using time series data spanning from 1980 to 2013 which were sourced from the World Bank Indicator and National Bureau of Statistics. The study employed Auto Regressive Distributed Lagged (ARDL) Co-integration analysis to estimate the relationship among the variables used in the study. The study established long-run co-integration among the variables. The findings from the study revealed that there is positive long-run relationship among secondary school enrolment, public expenditure on education, life expectancy rate, gross capital formation and economic growth but it is statistically insignificant. The results also showed that there is negative long-run relationship among primary, tertiary school enrolment, public expenditure on health and economic growth.

Amassoma and Ikechukwu [35] appraised the nexus between investment in Human capital development and economic growth in order to ascertain the impact of investment in human capital on economic growth in Nigeria. Data spanning 1970 - 2012 were used for the study. Two Stage Least Square (TSLS) and Pairwise Granger Causality methodologies were used to verify the empirical relationship between variables. The results of the TSLS showed that there exist a positive and statistically significant relationship between PERCAPITA and some explanatory variables (like; HUMANCAP, PUBLIC, and EXCHR) in the first estimated equation. The result also shows that LABFORCE exhibited a negative but significant effect on the level of PERCAPITA income in Nigeria.

\section{METHODOLOGY}

This study employed econometrics methodology in examining the relationship between human capital development and economic growth in Nigeria. The study was carried out for the period 1990 to 2018 and data were collected from the World Development Indicator, CBN Statistical Bulletin and NBS Statistical. The vector autoregressive (VAR) was used to establish the long run relationship among the variables (Human capital, Government expenditure on education, Government expenditure on health, Life expectancy, Fertility rate and GDP as proxy for economic growth).

\section{Model Specification}

The standard Cobb- Douglas production function provides the framework for the derivation of factors that drive output. The production function relates labour input, capital input and technological progress, i.e. the residual which cannot be explained by the quantity and quality of either labour or capital. The production function is stated as:

$$
Y=f(K, L)
$$

The aggregated production function to be estimated is specified as:

$$
Y_{t}=A_{t} K_{t}^{\propto} L_{t}^{\beta}
$$

Where $Y_{t}$ denotes aggregates output at time $(t)$ and $\mathrm{A}_{t}, \mathrm{~K}_{\mathrm{t}}$ and $\mathrm{L}_{\mathrm{t}}$ are total factor productivity, the capital stock and labour stock respectively. The standard APF assumes that, along with other 'conventional inputs' of capital and labour used in the neoclassical production function, 'unconventional inputs' may be included in the model to capture their contribution to output growth. We indicate all this unconventional inputs as: 


$$
W_{t}=f\left(W_{1} W_{2} W_{3} W_{4} W_{5} \ldots W_{n}\right)=W_{1 t}^{\infty} W_{2 t}^{\partial} W_{3 t}^{\emptyset} W_{4 t}^{\gamma} W_{5 t}^{\delta} \ldots W_{n t}^{\rho}
$$

We combine equation (2) and equation (3) to have:

$$
Y_{t}=A_{t} K_{t}^{\alpha} L_{t}^{\beta} W_{1 t}^{\infty} W_{2 t}^{\partial} W_{3 t}^{\phi} W_{4 t}^{\gamma} W_{5 t}^{\delta}
$$

Consequently, the equation specified with 'unconventional inputs' as enunciated in equ (4) to assess the causal relationship between human capital development and economic growth in Nigeria is specified functionally as follows:

$\mathrm{GDP}=\mathrm{f}(\mathrm{HC}, \mathrm{TER}, \mathrm{GXE}, \mathrm{GXH}, \mathrm{LI}, \mathrm{FER})$

Stating the equation 5 in an econometric form gives equation 6 below;

$G D P_{t}=\square_{0}+\square_{1} H C_{t}+\square_{2} G X E_{t}+\square_{3} G X H_{t}+\square_{4} L I_{t}+\square_{5} F E R_{t}+\square_{t}$

Where;

GDP $=$ Gross Domestic Product,

$\mathrm{HC}=$ human capital (Human capital development or HDI),

GXE $=$ Government expenditure on education,

GXH $=$ government expenditure on health,

LI $=$ Life Expectancy at time FER $=$ Fertility Rate at time t,

$\square_{0}=$ constant, $\quad \square_{1}-\square_{5}$ is the slope of the independent variables while $\square_{t}$ is the error term at time t.

The Vector autoregression (VAR) was used for long-run establishment while Impulse response Function was used for the response.

GDP

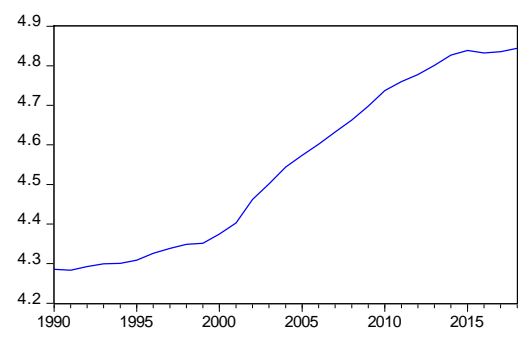

GXH

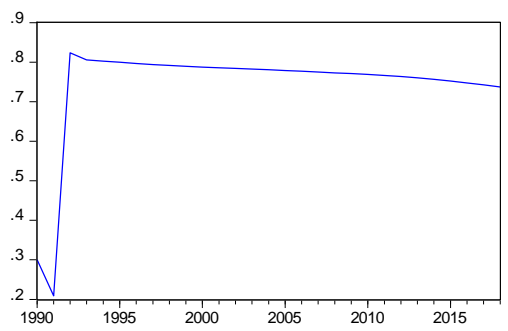

LE

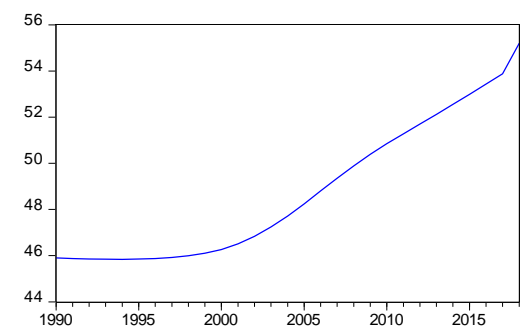

DATA PRESENTATION AND ANALYSIS OF RESULTS

\section{Presentation of Results}

The analysis of data is presented in this chapter. The first section is subdivided into introduction, descriptive statistics of the data in its original state; the unit root test, trend analysis and post estimation test such as stability and normality tests.

The study also carried out a cointegration test. For the estimation of the data, the study makes use of the Vector Autoregression (VAR). The data on the study range from 1990 to 2018 . The data were sourced from the CBN statistical Bulleting and the World Bank Development Indicators, 2019 version.
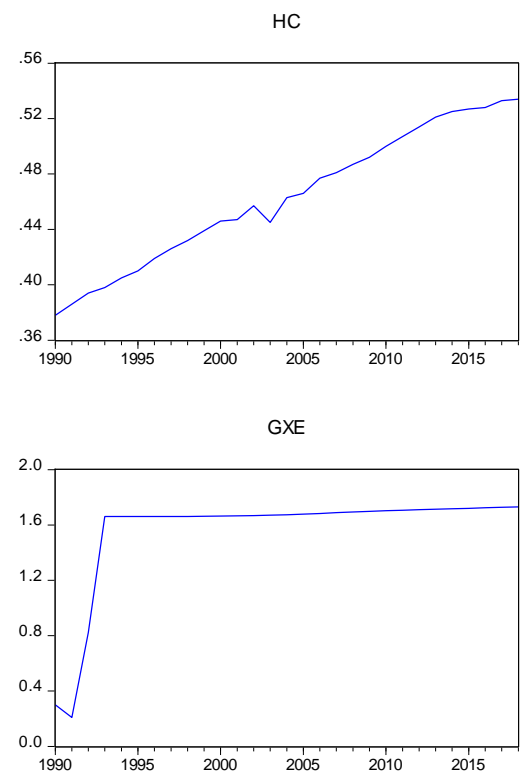

FER

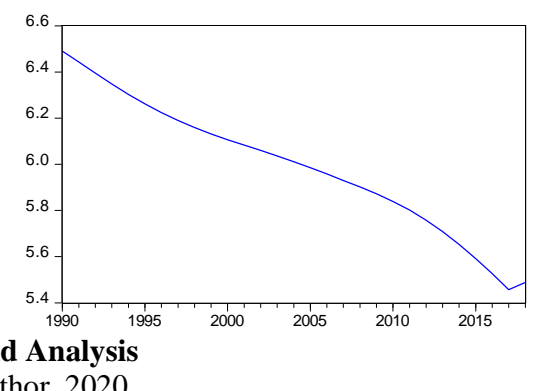


The Figure-1 above shows the movements in the variables during the period under review. GDP showed a positive or upward trend. Its peak was reached in 2015. Human capital is shown to have been increasing with its peak shown in 2018 while its lowest value was in 1990. Government expenditure on health and education also witnessed increasing trend. The figure also showed that life expectancy has been increasing with its peak in 2018 as fertility rate has been falling over the course of the years with its lowest value recorded in 2017.

Table-1: Descriptive statistics of the data

\begin{tabular}{|l|l|l|l|l|l|l|}
\hline & GDP & HC & GXH & GXE & LE & FER \\
\hline Mean & 4.546249 & 0.463345 & 0.741490 & 1.558636 & 48.76821 & 5.990034 \\
\hline Median & 4.544323 & 0.463000 & 0.777064 & 1.674310 & 47.71700 & 6.011000 \\
\hline Maximum & 4.843918 & 0.534000 & 0.823444 & 1.731387 & 55.20000 & 6.490000 \\
\hline Minimum & 4.283280 & 0.378000 & 0.208871 & 0.208871 & 45.84100 & 5.457000 \\
\hline Std. Dev. & 0.213314 & 0.049055 & 0.136829 & 0.395998 & 3.028132 & 0.288686 \\
\hline Skewness & 0.126248 & -0.091007 & -3.326688 & -2.801849 & 0.587065 & -0.173545 \\
\hline Kurtosis & 1.410706 & 1.777631 & 12.50136 & 9.215299 & 1.940626 & 2.178734 \\
\hline Jarque-Bera & 3.129111 & 1.845505 & 162.5732 & 84.62125 & 3.021866 & 0.960564 \\
\hline Probability & 0.209181 & 0.397424 & 0.000000 & 0.000000 & 0.220704 & 0.618609 \\
\hline Sum & 131.8412 & 13.43700 & 21.50321 & 45.20045 & 1414.278 & 173.7110 \\
\hline Sum Sq. Dev. & 1.274083 & 0.067379 & 0.524218 & 4.390794 & 256.7484 & 2.333517 \\
\hline Observations & 29 & 29 & 29 & 29 & 29 & 29 \\
\hline
\end{tabular}

Source: Author, 2020

Table- 1 showed that the mean and the median of the variables lie within minimum and maximum threshold. Meeting this criterion implies that the data is admissible for estimation and projection.

Table-2: The Results of Augmented Dickey-Fuller (ADF) and Phillips Perron (PP)

\begin{tabular}{|l|l|l|l|l|l|}
\hline \multicolumn{7}{|l|}{ Augmented Dickey-Fuller (ADF) } & Phillips Perron (PP) & & \\
\hline Variable & Level & $1^{\text {st }}$ difference & Level & 1 st difference & Remark \\
\hline FER & -0.51632 & $-6.84975^{* * *}$ & 1.502243 & $-6.9218^{* * *}$ & $1(1)$ \\
\hline HC & -1.4486 & $-2.23471^{* * *}$ & $-1.7401 *$ & -2.3496 & $\mathrm{I}(1)$ \\
\hline GDP & 1.6075 & $-4.5179 * * *$ & -0.6083 & $-4.9838^{* * *}$ & $\mathrm{I}(1)$ \\
\hline GXE & 1.3689 & $-3.1433^{* *}$ & 0.3285 & $-5.219 * * *$ & $\mathrm{I}(1)$ \\
\hline GXH & -2.372 & $-4.6176^{* * *}$ & -7.9818 & $-3.0304 * *$ & $\mathrm{I}(1)$ \\
\hline LE & $-8.7954 *$ & -0.1339 & -5.116798 & $-0.0001^{*}$ & $\mathrm{I}(1)$ \\
\hline
\end{tabular}

Source: Computed by the Author

Note; Asterisks $(*),(* *)$ and $(* * *)$ show the significance level at $10 \%, 5 \%$ and $1 \%$ level of significance respectively.

Decision rule: the null hypothesis is rejected if the tabulated value is greater than the critical value at a chosen level of significance. The statonarity test on human capital, GDP, government expenditure on education, government expenditure on health, fertility rate and life expectancy have shown to be stationary at first difference. This means that the stationarity level of the variables of the study are uniform of stationarity at first difference. None of the variables adopted in this study is stationary at second difference as this has a high tendency of leading to a spurious result. They are stationary because the ADF and PP calculated statistics are all less than the critical values of the ADF and PP at $5 \%$ levels of significance.

Table-3: Test for Cointegration

\begin{tabular}{|c|c|c|c|c|}
\hline \multicolumn{3}{|c|}{ Sample: 19902018} & & \\
\hline \multicolumn{4}{|c|}{ Included observations: 29} & \\
\hline \multicolumn{4}{|c|}{ Null hypothesis: Series are not cointegrated } & \\
\hline \multicolumn{4}{|c|}{ Cointegrating equation deterministics: $\mathrm{C}$} & \\
\hline \multicolumn{5}{|c|}{ Automatic lags specification based on Schwarz criterion (maxlag=6) } \\
\hline Dependent & tau-statistic & Prob.* & Z-statistic & Prob.* \\
\hline GDP & -2.565801 & 0.8949 & -13.19132 & 0.8080 \\
\hline $\mathrm{HC}$ & -3.965542 & 0.3553 & -178.2749 & 0.0000 \\
\hline GXH & -7.322328 & 0.0012 & -36.76136 & 0.0014 \\
\hline GXE & -5.389056 & 0.0454 & -29.20933 & 0.0379 \\
\hline LE & -1.918375 & 0.9820 & -10.22936 & 0.9291 \\
\hline FER & -3.034569 & 0.7462 & -14.51263 & 0.7332 \\
\hline
\end{tabular}


The result shown in the Table-3 above showed that there are three cointegarating factors viz human capital, government expenditure on health and government expenditure on education. The statistical significance of the three variables implies that the null hypothesis is rejected. It is therefore concluded that the variables of the model are cointegrated.

Table-4: Vector Auto regression (VAR)

\begin{tabular}{|c|c|c|c|c|c|c|}
\hline \multicolumn{3}{|c|}{ Vector Autoregressive Estimates } & & & \\
\hline \multicolumn{7}{|c|}{ Sample (adjusted): 19912018} \\
\hline \multicolumn{7}{|c|}{ Included observations: 28 after adjustments } \\
\hline \multicolumn{7}{|c|}{ Standard errors in ( ) \& t-statistics in [ ] } \\
\hline & GDP & $\mathrm{HC}$ & GXH & GXE & LE & FER \\
\hline \multirow[t]{3}{*}{ GDP(-1) } & 1.197082 & 0.087577 & -0.360349 & -0.414536 & 2.806412 & 0.028682 \\
\hline & $(0.09850)$ & $(0.04087)$ & $(0.86352)$ & $(1.02953)$ & $(1.40417)$ & $(0.15440)$ \\
\hline & {$[12.1537]$} & [2.14291] & {$[-0.41730]$} & {$[-0.40265]$} & [ 1.99862] & {$[0.18576]$} \\
\hline \multirow[t]{3}{*}{$\mathrm{HC}(-1)$} & 0.314091 & 0.554117 & 2.015693 & 2.395144 & -11.69688 & -0.467724 \\
\hline & $(0.07000)$ & $(0.19502)$ & $(4.12057)$ & $(4.91273)$ & $(6.70048)$ & $(0.73679)$ \\
\hline & {$[0.66828]$} & [2.84138] & {$[0.48918]$} & {$[0.48754]$} & {$[-1.74568]$} & {$[-0.63481]$} \\
\hline \multirow[t]{3}{*}{ GXH(-1) } & 0.123132 & -0.010001 & 0.344464 & 1.771546 & 0.061867 & -0.005194 \\
\hline & $(0.03580)$ & $(0.01485)$ & $(0.31384)$ & $(0.37417)$ & $(0.51033)$ & $(0.05612)$ \\
\hline & [3.43944] & {$[-0.67332]$} & {$[1.09759]$} & [ 4.73458] & {$[0.12123]$} & {$[-0.09256]$} \\
\hline \multirow{3}{*}{ GXE(-1) } & 0.110145 & 0.006906 & 0.002272 & 0.024953 & -0.227835 & -0.009085 \\
\hline & $(0.01673)$ & $(0.00694)$ & $(0.14666)$ & $(0.17486)$ & $(0.23849)$ & $(0.02622)$ \\
\hline & {$[6.58368]$} & {$[0.99500]$} & {$[0.01549]$} & {$[0.14271]$} & {$[-0.95534]$} & {$[-0.34643]$} \\
\hline \multirow[t]{3}{*}{$\mathrm{LE}(-1)$} & 0.021839 & -0.002490 & -0.008376 & -0.002586 & 0.783432 & -0.013643 \\
\hline & $(0.00591)$ & $(0.00245)$ & $(0.05179)$ & $(0.06175)$ & $(0.08422)$ & $(0.00926)$ \\
\hline & [3.69680] & {$[-1.01600]$} & {$[-0.16172]$} & {$[-0.04188]$} & [9.30220] & {$[-1.47316]$} \\
\hline \multirow[t]{3}{*}{ FER(-1) } & -0.028173 & -0.028685 & -0.000183 & -0.186855 & -3.081035 & 0.799023 \\
\hline & $(0.06597)$ & $(0.02737)$ & $(0.57839)$ & $(0.68958)$ & $(0.94052)$ & $(0.10342)$ \\
\hline & {$[-0.42704]$} & {$[-1.04791]$} & {$[-0.00032]$} & {$[-0.27097]$} & {$[-3.27589]$} & [7.72597] \\
\hline \multirow[t]{3}{*}{$\mathrm{C}$} & 0.226262 & 0.103743 & 1.611418 & 2.275549 & 22.32402 & 1.937280 \\
\hline & $(0.54123)$ & $(0.22457)$ & $(4.74502)$ & (5.65723) & $(7.71590)$ & $(0.84845)$ \\
\hline & [0.41805] & [0.46196] & {$[0.33960]$} & [0.40224] & [2.89325] & [2.28332] \\
\hline $\mathrm{R}$-squared & 0.997745 & 0.992191 & 0.353611 & 0.892217 & 0.997778 & 0.996785 \\
\hline Adj. R-squared & 0.997101 & 0.989960 & 0.168928 & 0.861422 & 0.997143 & 0.995867 \\
\hline Sum sq. resids & 0.002714 & 0.000467 & 0.208609 & 0.296526 & 0.551606 & 0.006670 \\
\hline S.E. equation & 0.011368 & 0.004717 & 0.099668 & 0.118829 & 0.162071 & 0.017821 \\
\hline F-statistic & 1548.859 & 444.6883 & 1.914694 & 28.97280 & 1571.459 & 1085.182 \\
\hline Log likelihood & 89.65099 & 114.2813 & 28.86272 & 23.93926 & 15.24949 & 77.06310 \\
\hline Akaike AIC & -5.903642 & -7.662948 & -1.561623 & -1.209947 & -0.589249 & -5.004507 \\
\hline Schwarz SC & -5.570591 & -7.329897 & -1.228571 & -0.876896 & -0.256198 & -4.671456 \\
\hline Mean dependent & 4.555555 & 0.466393 & 0.757242 & 1.603572 & 48.87071 & 5.972179 \\
\hline S.D. dependent & 0.211149 & 0.047075 & 0.109329 & 0.319209 & 3.032027 & 0.277197 \\
\hline \multicolumn{2}{|c|}{ Determinant resid covariance (dof adj.) } & $9.34 \mathrm{E}-25$ & & & & \\
\hline \multicolumn{2}{|c|}{ Determinant resid covariance } & $1.66 \mathrm{E}-25$ & & & & \\
\hline \multicolumn{2}{|l|}{ Log likelihood } & 560.4135 & & & & \\
\hline \multicolumn{2}{|c|}{ Akaike information criterion } & -37.02953 & & & & \\
\hline \multicolumn{2}{|l|}{ Schwarz criterion } & -35.03123 & & & & \\
\hline \multicolumn{2}{|c|}{ Number of coefficients } & 42 & & & & \\
\hline
\end{tabular}

Source: Computed by the Author from Eviews 10.

The long run result shows that Human capital (HC) has a significant positive relationship with GDP. The result shows that a $1 \%$ increase in $\mathrm{HC}$ will lead to $0.32 \%$ increase in GDP. The result also shows that government expenditure on education (GXE) has a significant positive relationship with GDP. The result shows that a $1 \%$ increase in government expenditure on education (GXE) will lead to $0.01 \%$ increase in GDP.
The finding corroborates the results of Matthew, Ogunnaike and Fasina [36] and Sieng and Yussof [37]. The result on government expenditure on health (GXH) shows a positive and significant relationship with GDP. The result shows a $1 \%$ change in government expenditure on health will lead to $0.12 \%$ change in the level of GDP in Nigeria. The result on the government expenditure on education (GXE) shows it has a positive 
significant relationship with GDP. The findings of the result revealed that a $1 \%$ increase in government expenditure on education will lead to $0.11 \%$ increase in economic growth in Nigeria. The result on life expectancy (LE) shows it has a positive significant relationship with GDP. The result shows that an increase in life expectancy by $1 \%$ will lead to $0.02 \%$ increase in GDP. Fertility rate (FER) shows it has a negative significant relationship with the level of GDP. The result shows that an increase in fertility rate by $1 \%$ will lead to a reduction of $0.02 \%$ in GDP. The adjusted $\mathrm{R}$-squared represents the percentage of the behavior of the dependent variable that is explained by the independent variables. The result has shown that the independent variables account for $99.7 \%$ of the behaviour of the dependent variables in the model.

Response to Cholesky One S.D. (d.f. adjusted) Innovations \pm 2 S.E.

Response of GDP to HC

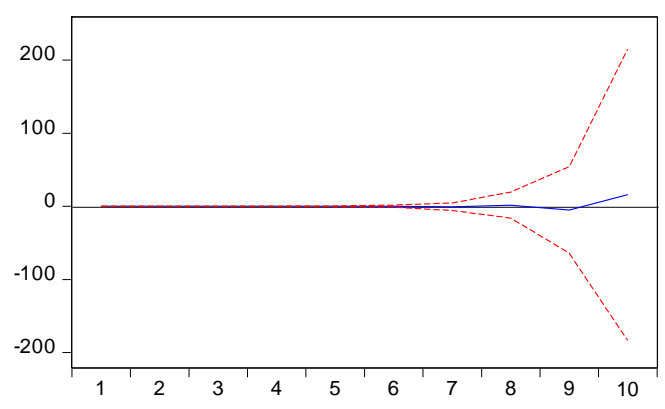

Response of GDP to GXE

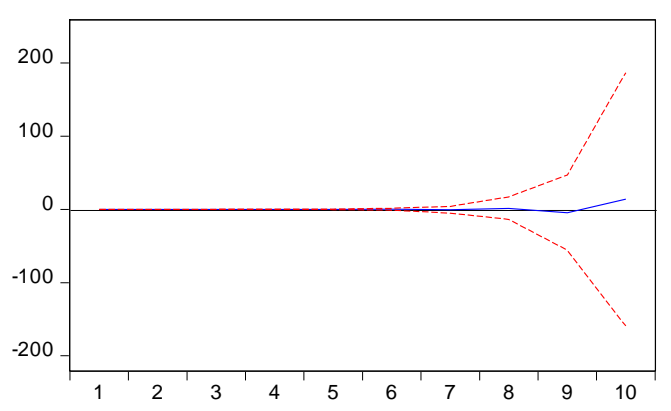

Response of GDP to FER

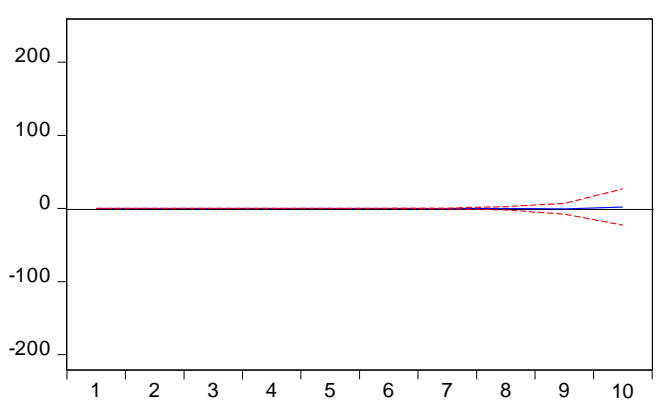

Response of GDP to GXH

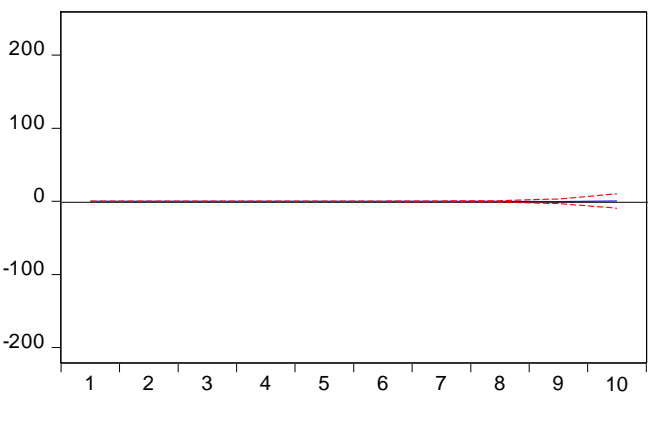

Response of GDP to LE

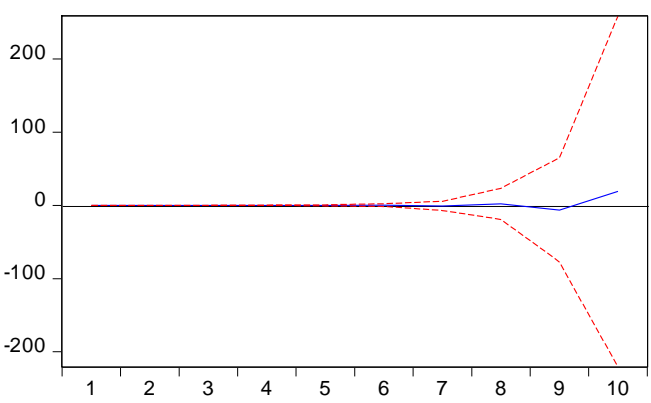

Fig-2: Impulse Response Function

Source: Author, 2020

Figure-2 above shows impulse response function. It shows that a one standard deviation change in human capital brings about a positive insignificant change in the level of GDP. Also, a one standard deviation change in government expenditure on health brings about a non-significant change in the GDP. Also, the figure shows a one standard deviation change in the government expenditure on health will lead to a positive and significant change in the GDP. The result implies that an increase in the government expenditure on health will lead to a higher level of GDP. Also, the fourth box has shown that a one standard deviation change in life expectancy will lead to a positive significant change in the GDP. The result as shown from the fifth box shows a one standard deviation change in the fertility rate will lead to a non-significant change in the GDP. 
Table-5: Serial correlation, model

\begin{tabular}{|l|l|l|l|l|l|l|}
\hline $\begin{array}{l}\text { Null Hypothesis: No serial correlation } \\
\text { Sample: } 19902018\end{array}$ & & & & \\
\hline \multicolumn{2}{|l|}{ Included observations: 27} & & & & \\
\hline Lag & LRE* stat & Df & Prob. & Rao F-stat & Df & Prob. \\
\hline 1 & 78.52577 & 36 & 0.0001 & 4.360488 & $(36,15.9)$ & 0.1014 \\
\hline 2 & 62.35504 & 36 & 0.0041 & 2.496968 & $(36,15.9)$ & 0.2267 \\
\hline 3 & 71.31027 & 36 & 0.0004 & 3.415492 & $(36,15.9)$ & 0.5055 \\
\hline
\end{tabular}

The correlation result from Figure-5 above shows it is statistically insignificance $(0.05)$ at $5 \%$, this implies we accept the null hypothesis that no correlation exists among the variables. There absence of correlation shows the data of the study are good and fit for estimation.

Table-6: Heteroskedasticity

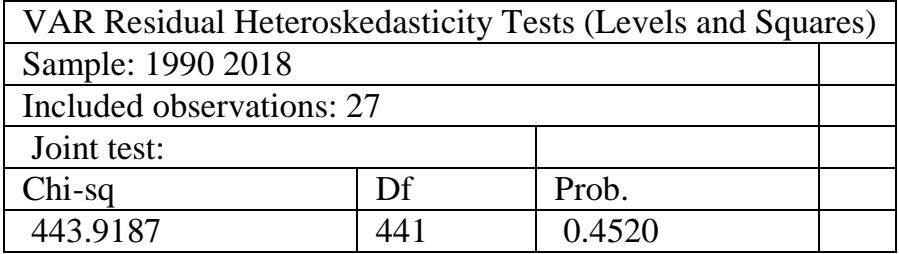

Source: Author, 2020

Table-6 above shows the result on heteroskedasticity. The result shows it is not significant as this implies that the model is ok and it is free from the problem of heteroscedasticity.

\section{CONCLUSION \& RECOMMENDATIONS}

This result has been able to uncover that human capital (HR), government expenditure on education (GXE), government expenditure on health $(\mathrm{GXH})$ and life expectancy (LE) has significant impact on gross domestic product (GDP). This shows that depth of human capital development components cannot be undermined in Nigeria's quest for maintaining sustainable economic growth (GDP). This result has significant implication for deliberate investment in human resources for economic sustainability in Nigeria.

Furthermore, the result showed an inverse significant relationship between fertility rate (FE) and economic growth (GDP) in Nigeria. This is understandable given that increasing fertility rate (FE) invariably results to population growth with concomitant increased cost of investing in human capital development and depletion in natural resources occasioned by demand pressure on the utilization of natural resources for economic activities to sustain the teeming population. This clearly indicate that all efforts by the government and international community that is geared towards population control would not only positively impact the quality of life but further increase the availability and quality of labor force for productivity.
Based on the findings, the following recommendations were made for policy implementation:

Firstly, the Nigerian government should evolve practicable framework for improved investment in key human capital development deliverables especially education and health which remains germane to labour productivity and economic development. It is imperative to note that the quality of manpower, education and health is a reflection of total expenditure in these sectors with concomitant attendant implications on the level of productivity.

Secondly, the federal government of Nigeria should recognize that efforts towards improving the health service standards and meeting the health needs of citizens is tantamount to promoting the quality of labour force in the county. Therefore, a national health policy (for the working class) should be established by the federal government with the objective of subsidizing the cost of quality health services provided by health practitioners nurses, midwives, gynecologist, obstetricians, doctors among other, and raising a healthy labour force for the world of work.

Additionally, the government should enthusiastically pursue population control policies premised on the need to take advantage of the teeming population while assuaging their negative effects on economic development.

Lastly, the country must evolve a workable methodological framework to infuse a technological based curriculum in the educational sector in tandem with changes in the global economies. The workforce must be aligned to recent human capital requirement in the global context to guarantee favourable competitiveness. 


\section{REFERENCES}

1. Urs Rohner. (2018). Eradicating extreme poverty Research Institute Thought Leadership From Credit Suisse Research And The World's Foremost Experts.

2. Ministry of Budget and National Planning. (2017). The Nigerian Economic Plan: Economic Recovery and Growth Plan 2017-2020 published February, 2017.

3. Central Bank of Nigeria (2018). Statistical bulletin, volume 29. https://www.cbn.gov.ng/documents/Statbulletin.as p.

4. Ogunleye, O. O., Owolabi, O. A., \& Mubarak, M. (2018). Population growth and economic growth in Nigeria: An appraisal. International Journal of Management, Accounting and Economics, 5(5), 283-299.

5. UNICEF, Nigeria Country Office, The Children Education (2015), UNICEF, Nigeria information sheet Girls Education. Abuja: Nigeria Country Office.

6. World Bank. (2016). Nigeria Biannual Economic Update Investing in HUMAN CAPITAL Nigeria's future retrieved from http://documents.worldbank.org/curated/en/37316 1558953247137/pdf/Investing-in Human-Capitalfor-Nigeria-s-Future-Nigeria-Biannual-EconomicUpdate.pdf

7. Adenikinju, A. F. (2005). Productivity performance in developing countries: Country case studies, Nigeria. Washington D. C.: UNIDO.

8. Oshiomhole, A. A. (2006). Labour and productivity in Nigeria: The Private and public sector dilemma. Being Text of Lecture Delivered at the Department of Psychology University of Ibadan 3rd. February, 2006.

9. Bassey, O. E., \& Peter, S. U. (2017) Education Expenditure and Access to Education: Case Study of United Nations Educational, Scientific and Cultural Organization Declaration in Nigeria. International Journal of Economics and Financial issues, 7(5),290-298.

10. Adamu, P. A. (2003). The Impact of Human Capital on Economic Growth in Nigeria: An Error Correction Approach. Paper presented at the 2002 Annual Conference of the Nigeria Economic Society, Nigeria.

11. Adelakun, O. J. (2011). Human Capital Development and Economic Growth in Nigeria. European Journal of Business and Management, 3, 9(2).

12. Fuente, A. D. (2009). Education and Economic Growth; A Quick Review of the Evidence and Some Policy Guidelines" A Paper presented "Globalization and Challenges for Europe and Fairland organized by the secretariat of the Economic Council.

13. Ibok, E. E., \& Ibanga, S. E. (2014). The impact of human capital development and economic empowerment on the socio-economic development of Akwa Ibam State, Nigeria. Global Journal of Human Resource Management, 2(3): 37-44.

14. Awopegba, P. O. (2003). Human Resources, Highlevel Manpower and the Development of the Nigerian Economy. In Iyoha, M. A., \& Itsede, C. $\mathrm{O}$ (Eds) Nigerian Economy: structure, growth and development. Benin City: Mindex Publishing Co. Ltd. 105-135.

15. Romele, L. (2013). Human capital development and economic growth in Latvia. European Scientific Journal, 9(31).

16. Bernanke, B. S., \& Frank, R. H. C. (2007). Principios de economía(No. Ae1780). McGraw-Hill,.

17. World Bank. (2018) World Development Report 2018: Learning to Realize Education's Promise. Washington, DC: World Bank.

18. Todaro, M. P., \& Smith, S. C. (2011). Economic Development. 11th edn. Harlow.

19. Lawanson A. O. (2009). Economic growth experience of West African region: does human capital matter? International Journal of Business and Social Science 6(12).

20. Todaro, M. P., \& Smith, S. C. (2009). Economic Development. Harlow.

21. Todaro M. P., \& Smith, S. C. (2003). Economic development (Eighth Edition), India: Pearson Education (Singapore) Pte Ltd.

22. Saif. (2018). What is the role of human capital in economic development? Owlcation, 2-4.

23. Edame, G. E., \& Eturoma, A. D. (2014). The determinants of public expenditure on educational infrastructural facilities and economic growth in Nigeria. Journal of Business Management and Economics, 5(6):152-161.

24. Uduh, D. M., \& Azu, B. C. (2017). Human Capital Development and Economic Growth in Nigeria; The Role of Nomadic Education. International Journal of Asian Social Science, 7(11), 931-941.

25. Monimah, H. D. (2010). The centrality of human capital development to the attainment of Nigeria's Vision 2020:20 development programme. Journal of Sustainable Development in Africa, 12(5): 139155.

26. Romer, P. (1986). Increasing returns and long run growth. The Journal of Political Economy, 94, 1002-1037.

27. Barro, R. J., Mankiw, G., \& Sala-i-Martin, X. (1995). Capital mobility and economic growth. Amer. Econ. Rev, 85(1), 103-115.

28. Lucas, R. E. (1988). On the Mechanics of Economic Development. Journal of Monetary Economics. 22, 12-23.

29. Aharonovitz, G. (2007). Expansion of firms and human capital accumulation by training: A growth model for the not-so-growing. Available at www.wsu.edu Retrieved on April 07, 2017

30. Marchand, M., Michel, P., Paddison, O., \& Pestieau, P. (2003). Optimal education subsidy and 
taxes in an endogenous growth model with human capital, Available at http://www.core.ucl.ac.be/services/psfiles /dp03/dp2003-19.pdf. Retrieved on September 01, 2016.

31. Eicher, T., \& Penalosa, C. G. (1999). Inequality and growth: The dual role of human capital in development. Available at www.eheschrs-mrs.fr. Retrieved on April 17, 2017.

32. Kairo, C. I., Mang N. J., Okeke, A., \& Aondo, D. C. (2017). Government expenditure and human capital development in Nigeria: An auto-regressive distributed lagged model approach (ARDL). International Journal of Advanced Studies in Economics and Public Sector Management. 5(1):143-158.

33. Obialor, M. C. (2017). Effect of government human capital investment on economic growth in Sub-Saharan Africa: Evidence from Nigeria, South
Africa and Ghana. International Journal of Asian Social Science. 7(4): 328-339.

34. Adeyemi, P. A., \& Ogunsola, A. J. (2016). The impact of human capital development on economic growth in Nigeria: ARDL Approach. Journal of Humanities and Social Science, 21(3):1-7.

35. Amassoma, D., \& Ikechukwu, E. (2016). A reappraisal of the nexus between investment in human capital development and economic growth in Nigeria. Journal of Entrepreneurship, Business and Economics, 4(2): 59-93.

36. Matthew, A. O., Ogunnaike, O. O., \& Fasina, F. F. (2008). Human Capital Investment: Effects on Economic Growth in Nigeria (1970-2004). Labour Law Review, 2(1):111-125.

37. Sieng, L. W., \& Yussof, I. (2014). Human Capital Accumulation and Economic Growth in Malaysia - Investigating the Long Run Nexus. Malaysian Journal of Economics. 48(1):155-165. 